\title{
Analisis Kemampuan Representasi Matematis pada Materi Barisan dan Deret Berdasarkan Gaya Belajar
}

\author{
Baiq Rachmawatin Ramadhana ${ }^{1, \text { a) }}$, Sudi Prayitno ${ }^{2, \text { b) }}$, Nourma Pramestie Wulandari ${ }^{3, \text { c) }}$, Sri \\ Subarinah ${ }^{4, d)}$ \\ ${ }^{1234}$ Universitas Mataram, Mataram, Nusa Tenggara Barat \\ Email penulis: ${ }^{\text {a) }}$ baiqrachmawatin99@gmail.com, ${ }^{\text {b) }}$ s.prayitno@unram.ac.id, ${ }^{\text {c) }}$ nourmapw @unram.ac.id, \\ d)s.subarinah@gmail.com
}

\begin{abstract}
This study aims to describe the mathematical representation ability based on the learning styles of students for 11th grade of senior high school 4 Praya Academic year 2020/2021. Type of research used descriptive research with a quantitative approach. In determining the sample used purposive sampling technique. The sample in this study was 60 students of class XII MIPA 4 and XII MIPA 6 SMAN 4 Praya. According results of the research, the conclusion was mathematical representation ability of students with visual learning style reach 51.59 in very low category. The mathematical representation ability of students with auditory learning style reach 64.29 in medium category. The mathematical representation ability of students with kinesthetic learning styles reach 49.89 in very low category. The mathematical representation ability of students with auditory learning style has highest category than students with visual and kinesthetic learning styles.
\end{abstract}

Keywords: Representation, Mathematical Representation, Mathematical Representation Ability, Learning Style, Sequence and Series

\begin{abstract}
Abstrak
Penelitian ini bertujuan untuk mendeskripsikan kemampuan representasi matematis pada materi barisan dan deret berdasarkan gaya belajar siswa kelas XI SMA Negeri 4 Praya Tahun Ajaran 2020/2021. Jenis penelitian yang digunakan adalah penelitian deskriptif dengan pendekatan kuantitatif. Dalam menentukan sampel digunakan teknik pengambilan purposive sampling. Sampel dalam penelitian ini adalah siswa kelas XII MIPA 4 dan XII MIPA 6 SMAN 4 Praya berjumlah 60 orang. Berdasarkan hasil penelitian, dapat disimpulkan bahwa kemampuan representasi matematis siswa bergaya belajar visual sebesar 51,59 berkategori sangat rendah. Kemampuan representasi matematis siswa bergaya belajar auditorial sebesar 64,29 berkategori sedang. Kemampuan representasi matematis siswa bergaya belajar kinestetik sebesar 49,89 berkategori sangat rendah. Kemampuan representasi matematis siswa bergaya belajar auditorial memiliki kategori paling tinggi dibandingkan dengan siswa bergaya belajar visual dan kinestetik.
\end{abstract}

Kata kunci: Representasi, Representasi Matematis, Kemampuan Representasi Matematis, Gaya Belajar, Barisan dan Deret

Copyright (c) 2022 Ramadhana, Prayitno, Wulandari, Subarinah

$\triangle$ Corresponding author:

Email Address: baiqrachmawatin99@gmail.com

Received 21 Januari 2022, Accepted 23 Februari 2022, Published 24 Februari 2022

https://doi.org/10.21009/jrpmj.v4i1.23025

\section{PENDAHULUAN}

Matematika memiliki banyak peranan yang sangat penting dalam berbagai aspek kehidupan manusia. Permasalahan dalam kehidupan sehari-hari dapat diselesaikan dengan menggunakan matematika (Komala \& Afrida, 2020). Oleh karena itu, matematika dipelajari di berbagai jenjang pendidikan agar siswa memiliki dasar pengetahuan matematika yang kuat. Selain itu, matematika merupakan bidang ilmu yang dapat meningkatkan kemampuan seseorang dalam berfikir secara logis, 
rasionalis, kritis, cermat, efektif dan efesien serta untuk mencapai hal tersebut, dibutuhkan pemahaman dan kompetensi matematika yang baik (Febrian dkk, 2016).

Lima standar yang perlu dimiliki siswa yaitu pemahaman, pengetahuan dan keterampilan dalam standar proses yang meliputi pemecahan masalah (problem solving), penalaran dan bukti (reasoning and proof), komunikasi (communication), koneksi (connection), representasi (representation) (NCTM, 2000). Representasi menjadi salah satu tujuan pembelajaran matematika di sekolah yang tercantum dalam Permen No. 22 Tahun 2016 (Kemendikbud, 2016). Representasi yang dimunculkan oleh siswa merupakan ungkapan dari gagasan-gagasan atau ide-ide matematis yang ditampilkan sebagai hasil dari interpretasi pikiran siswa dalam upaya mencari solusi dari masalah yang sedang dihadapi (NCTM, 2000). Representasi matematis adalah suatu bentuk dari menggambarkan dan menyimbolkan kembali gagasan objek matematika yang telah dipelajari oleh siswa (Yenni dan Sukmawati, 2020). Representasi matematis merupakan ungkapan-ungkapan ide matematika yang ditampilkan siswa untuk menyelesaikan masalah yang dihadapi sebagai hasil interpretasi pikiran siswa yang berupa kata-kata atau verbal, tulisan, gambar, tabel, grafik, dan simbol matematika. Proses representasi juga sebagai penerjemah masalah atau ide-ide ke dalam bentuk baru yang mencakup konversi diagram atau model fisik menjadi simbol atau kata-kata (Prayitno dkk, 2021).

Pentingnya kemampuan representasi matematis mengharuskan siswa untuk mampu: (1) menciptakan dan menggunakan representasi untuk mengorganisir, mencatat, dan mengkomunikasikan ide-ide matematis, (2) memilih, menerapkan, dan menerjemahkan representasi matematis untuk memecahkan masalah, (3) menggunakan representasi untuk memodelkan dan menginterpretasikan fenomena fisik, sosial, dan fenomena matematis (NCTM, 2000). Kemampuan representasi matematis siswa penting dalam proses pembelajaran matematika. Hal ini dikarenakan interpretasi dan penerjemahan dari representasi merupakan alat untuk menyampaikan pemikiran aljabar siswa sebagai bantuan untuk mengkonstruksi gambaran ide tentang pola dan fungsi (Tyas dan Sujadi, 2016). Dengan demikian, kemampuan representasi matematis diperlukan siswa untuk menemukan dan membuat suatu alat atau cara berpikir dalam mengkomunikasikan gagasan matematis dari yang sifatnya abstrak menuju konkret, sehingga lebih mudah untuk dipahami. Nurhayati dan Subekti (2017) menyebutkan bahwa salah satu faktor yang dapat mempengaruhi kemampuan representasi matematis siswa adalah gaya belajar. Gaya belajar merupakan cara belajar yang dimiliki seseorang dalam proses pembelajaran yaitu menyeleksi, menerima, menyerap, menyimpan, mengolah, dan memproses informasi (Ridwan, 2017). Mite dkk (2016) menyebutkan bahwa tidak semua orang memiliki gaya belajar yang sama. Seseorang yang bersekolah di sekolah yang sama atau duduk di kelas yang sama dapat memiliki gaya belajar yang berbeda. 
Anggraeni dan Suyahya (2016) menyatakan bahwa berdasarkan prefensi sensori atau kemampuan yang dimiliki otak dalam menyerap, mengelola dan menyampaikan informasi, maka gaya belajar seseorang dapat dibagi menjadi 3 (tiga) kategori yaitu gaya belajar visual, auditorial dan kinestetik. Hal ini menyiratkan bahwa untuk menunjukkan kemampuan representasi matematis dalam menyelesaikan suatu permasalahan matematika, siswa berusaha mengingat kembali pengetahuanpengetahuan yang diperoleh sebelumnya (Febrian dkk, 2016). Sehingga mendapatkan petunjuk untuk menyelesaikan permasalahan matematika yang ada. Petunjuk yang siswa dapat merupakan suatu aktivitas berpikir matematika baik secara visual, auditorial dan kinestetik. Berdasarkan uraian tersebut menjelaskan bahwa gaya belajar visual, auditorial dan kinestetik juga ikut mewarnai kemampuan representasi matematis siswa (Komala dan Afrida, 2020). Tujuan penelitian ini adalah untuk mendeskripsikan bagaimana kemampuan representasi matematis siswa yang memiliki gaya belajar visual, gaya belajar auditorial dan gaya belajar kinestetik pada materi barisan dan deret.

\section{METODE}

Pendekatan yang digunakan pada penelitian ini adalah kuantitatif dengan metode deskriptif kuantitatif dengan tujuan untuk mendeskripsikan dan menganalisis kemampuan representasi matematis siswa berdasarkan gaya belajar kelas XI SMA Negeri 4 Praya dalam menyelesaikan masalah yang berkaitan dengan materi barisan dan deret. Kelas yang dipilih merupakan kelas yang lebih heterogen dibandingkan kelas lainnya. Sehingga dipilih siswa kelas XII MIPA 4 dan XII MIPA 6 menjadi subjek penelitian. Subjek penelitian yang digunakan pada penelitian ini berjumlah 60 siswa yaitu 30 siswa kelas XII MIPA 4 dan 30 siswa kelas XII MIPA 6.

Teknik pengumpulan data pada penelitian ini yaitu menggunakan angket, tes dan wawancara. Instrumen penelitian yang digunakan yaitu lembar angket, tes representasi matematis dan pedoman wawancara. Lembar angket gaya belajar ini digunakan untuk mendapatkan data mengenai gaya belajar yang dimiliki oleh siswa. Instrumen angket gaya belajar disusun dengan 5 butir soal gaya belajar visual, 5 butir soal jenis gaya belajar auditorial dan 5 butir soal jenis gaya belajar kinestetik. Adapun kisi-kisinya dapat dilihat pada Tabel 1 berikut.

Tabel 1. Kisi-kisi Angket Gaya Belajar

\begin{tabular}{ccc}
\hline Indikator & Item Soal & Jumlah Item \\
\hline Visual & $1,4,7,10,13$ & 5 \\
\hline Auditorial & $2,5,8,11,14$ & 5 \\
\hline Kinestetik & $3,6,9,12,15$ & 5 \\
\hline \multicolumn{2}{c}{ Jumlah } & 15 \\
\hline
\end{tabular}

Lembar tes representasi matematis ini digunakan untuk mengetahui kemampuan representasi matematis siswa pada materi barisan dan deret. Adapun tes yang digunakan berupa tes uraian. Adapun kisi-kisi soal tes representasi berdasarkan bentuk operasional representasi menurut Dahlan dan Juandi (2011) dapat dilihat pada Tabel 2 berikut. 
Tabel 2. Kisi-kisi Soal Tes Representasi

\begin{tabular}{lcl}
\hline Indikator/bentuk Representasi & Nomor Soal & \multicolumn{1}{c}{ Bentuk Opersional } \\
\hline Visual & $1,2,3$ & $\begin{array}{l}\text { Membuat representasi visual dari } \\
\text { sebuah masalah matematis }\end{array}$ \\
\hline Ekspresi Matematis & $1,2,3$ & $\begin{array}{l}\text { Membuat persamaan atau model } \\
\text { matematis dari permasalahan atau } \\
\text { informasi yang diberikan }\end{array}$ \\
\hline Verbal/Kata-kata & $1,2,3$ & $\begin{array}{l}\text { Menuliskan langkah-langkah } \\
\text { penyelesaian dengan kata-kata }\end{array}$ \\
\hline
\end{tabular}

Tabel 3 berikut merupakan kriteria pedoman penyekoran kemampuan representasi matematis pada penelitian ini yang dimodifikasi dari kriteria pedoman penyekoran (Lestari dan Yudhanegara, 2017).

Tabel 3. Kriteria Penyekoran Kemampuan Representasi Matematis

\begin{tabular}{|c|c|c|c|}
\hline No & $\begin{array}{l}\text { Indikator Kemampuan Representasi } \\
\text { Matematis }\end{array}$ & Deskripsi & Skor \\
\hline \multirow[t]{5}{*}{1.} & \multirow{5}{*}{$\begin{array}{l}\text { Representasi visual, } \\
\text { kemampuan membuat representasi } \\
\text { visual dari sebuah masalah }\end{array}$} & $\begin{array}{l}\text { Melukiskan gambar secara lengkap, } \\
\text { benar dan sistematis. }\end{array}$ & 4 \\
\hline & & $\begin{array}{l}\text { Melukiskan gambar secara lengkap } \\
\text { dan benar. }\end{array}$ & 3 \\
\hline & & $\begin{array}{l}\text { Melukiskan gambar namun kurang } \\
\text { lengkap dan benar. }\end{array}$ & 2 \\
\hline & & $\begin{array}{l}\text { Hanya sedikit dari gambar yang } \\
\text { benar. }\end{array}$ & 1 \\
\hline & & $\begin{array}{l}\text { Tidak ada jawaban, kalaupun ada } \\
\text { hanya memperlihatkan ketidak } \\
\text { pahaman tentang konsep sehingga } \\
\text { informasi yang diberikan tidak berarti } \\
\text { apa-apa. }\end{array}$ & 0 \\
\hline \multirow[t]{5}{*}{2.} & \multirow[t]{5}{*}{$\begin{array}{l}\text { Representasi persamaan atau ekspresi } \\
\text { matematis, yaitu kemampuan dalam } \\
\text { membuat persamaan atau model } \\
\text { matematis. }\end{array}$} & $\begin{array}{l}\text { Menemukan model matematika } \\
\text { dengan benar, kemudian melakukan } \\
\text { perhitungan atau mendapatkan solusi } \\
\text { secara benar dan lengkap secara } \\
\text { sistematis. }\end{array}$ & 4 \\
\hline & & $\begin{array}{l}\text { Menemukan model matematika } \\
\text { dengan benar, kemudian melakukan } \\
\text { perhitungan atau mendapatkan solusi } \\
\text { secara benar dan lengkap. }\end{array}$ & 3 \\
\hline & & $\begin{array}{l}\text { Menemukan model matematika } \\
\text { dengan benar, namun salah } \\
\text { mendapatkan solusi. }\end{array}$ & 2 \\
\hline & & $\begin{array}{l}\text { Hanya sedikit dari model matematika } \\
\text { yang benar. }\end{array}$ & 1 \\
\hline & & $\begin{array}{l}\text { Tidak ada jawaban, kalaupun ada } \\
\text { hanya memperlihatkan ketidak } \\
\text { pahaman tentang konsep sehingga } \\
\text { informasi yang diberikan tidak berarti } \\
\text { apa-apa. }\end{array}$ & 0 \\
\hline 3. & $\begin{array}{l}\text { Representasi verbal, yaitu } \\
\text { kemampuan dalam menuliskan } \\
\text { langkah-langkah penyelesaian dengan }\end{array}$ & $\begin{array}{l}\text { Penjelasan secara matematis masuk } \\
\text { akal dan jelas serta tersusun secara } \\
\text { logis dan sistematis. }\end{array}$ & 4 \\
\hline
\end{tabular}




\begin{tabular}{|c|c|c|c|}
\hline No & $\begin{array}{l}\text { Indikator Kemampuan Representasi } \\
\text { Matematis }\end{array}$ & Deskripsi & Skor \\
\hline & \multirow[t]{4}{*}{ kata-kata. } & $\begin{array}{l}\text { Penjelasan secara matematis masuk } \\
\text { akal dan benar, meskipun tidak } \\
\text { tersusun secara logis atau terdapat } \\
\text { sedikit kesalahan bahasa }\end{array}$ & 3 \\
\hline & & $\begin{array}{l}\text { Penjelasan secara matematis masuk } \\
\text { akal namun hanya sebagian lengkap } \\
\text { dan benar. }\end{array}$ & 2 \\
\hline & & $\begin{array}{l}\text { Hanya sedikit dari penjelasan yang } \\
\text { benar. }\end{array}$ & 1 \\
\hline & & $\begin{array}{l}\text { Tidak ada jawaban, kalaupun ada } \\
\text { hanya memperlihatkan ketidak } \\
\text { pahaman tentang konsep sehingga } \\
\text { informasi yang diberikan tidak berarti } \\
\text { apa-apa. }\end{array}$ & 0 \\
\hline
\end{tabular}

Dari hasil tes, kemudian ditentukan bagaimana kemampuan representasi visual, simbolik dan verbal pada siswa yang memiliki gaya belajar visual, auditorial dan kinestetik. Kemudian dipilih masingmasing 2 siswa dari setiap gaya belajar untuk melakukan wawancara. Wawancara dalam penelitian ini bertujuan untuk memperkuat jawaban siswa dan menggali informasi lebih mendalam tentang kemampuan representasi matematis siswa pada materi barisan dan deret. Validitas instrumen yang digunakan yaitu validitas Aiken. Teknik analisis data yang digunakan pada penelitian ini yaitu teknik analisis deskriptif kuantitatif dengan rumus mean dalam persentase.

Prosedur dalam penelitian ini terdiri dari tiga tahap, yaitu: 1) tahap persiapan meliputi: membuat instrumen angket, soal tes dan pedoman wawancara, 2) tahap pelaksanaan meliputi: memberikan angket gaya belajar dan soal tes materi barisan dan deret kepada siswa, melakukan wawancara terhadap perwakilan siswa dari masing-masing gaya belajar dan mengumpulkan seluruh data berupa hasil angket, tes dan wawancara, 3) tahap akhir meliputi: melakukan analisis data, menafsirkan dan membahas hasil analisis data kemampuan representasi matematis berdasarkan gaya belajar, menarik kesimpulan dari hasil penelitian dan menuliskan laporan.

\section{HASIL DAN PEMBAHASAN}

Berdasarkan hasil perhitungan dengan menggunakan rumus Aiken's V, diperoleh rata - rata validitas isi instrumen angket gaya belajar, soal tes representasi matematis dan pedoman wawancara untuk mengetahui kemampuan representasi matematis siswa berdasarkan gaya belajar pada Tabel 4 berikut. 
Tabel 4. Rata-rata Validitas Isi Instrumen Angket, Soal Tes dan Pedoman Wawancara

\begin{tabular}{cccc}
\hline No. & Validitas Isi & Rata-rata & Kategori \\
\hline 1 & Angket Gaya Belajar & 0,84 & Tinggi \\
\hline 2 & Soal Tes Representasi & 0,83 & Tinggi \\
\hline 3 & Pedoman Wawancara & 0,82 & Tinggi \\
\hline
\end{tabular}

Tabel 4 di atas menunjukkan bahwa rata-rata validitas isi instrumen angket gaya belajar, tes representasi matematis dan pedoman wawancara memiliki tinggi. Sehingga telah memenuhi kriteria untuk dijadikan alat pengambilan data dalam penelitian.

Hasil perolehan angket gaya belajar yaitu siswa yang memiliki gaya belajar visual berjumlah 21 siswa dengan persentase 35\%, siswa yang memiliki belajar auditorial berjumlah 14 siswa dengan persentase 23,33\% dan siswa yang memiliki gaya belajar kinestetik berjumlah 25 siswa dengan persentase 41,66\% dari total keseluruhan 60 siswa. Hal ini menunjukkan bahwa jumlah siswa dengan gaya belajar kinestetik lebih banyak dibandingkan dengan gaya belajar visual dan auditorial. Berikut Tabel 5 kriteria kemampuan representasi matematis dalam menyelesaikan soal representasi matematis materi barisan dan deret berdasarkan gaya belajar.

Tabel 5. Kriteria Kemampuan Representasi Matematis dalam Menyelesaikan Soal Representasi Matematis Materi Barisan dan Deret Berdasarkan Gaya Belajar

\begin{tabular}{|c|c|c|c|c|c|c|c|}
\hline \multirow{3}{*}{ No. } & \multirow{3}{*}{$\begin{array}{l}\text { Indikator } \\
\text { Kemampuan } \\
\text { Representasi } \\
\text { Matematis }\end{array}$} & \multicolumn{6}{|c|}{ Gaya Belajar } \\
\hline & & \multicolumn{2}{|c|}{ Visual } & \multicolumn{2}{|c|}{ Auditorial } & \multicolumn{2}{|c|}{ Kinestetik } \\
\hline & & $\begin{array}{c}\text { Rata- } \\
\text { rata }\end{array}$ & Kriteria & $\begin{array}{c}\text { Rata- } \\
\text { rata }\end{array}$ & Kriteria & $\begin{array}{c}\text { Rata- } \\
\text { rata }\end{array}$ & Kriteria \\
\hline 1 & Representasi Visual & 48,81 & $\begin{array}{l}\text { Sangat } \\
\text { rendah }\end{array}$ & 61,91 & Rendah & 54,33 & $\begin{array}{l}\text { Sangat } \\
\text { rendah }\end{array}$ \\
\hline 2 & $\begin{array}{c}\text { Representasi } \\
\text { Simbolik }\end{array}$ & 57,54 & Rendah & 67,86 & Sedang & 59,00 & Rendah \\
\hline 3 & Representasi Verbal & 44,05 & $\begin{array}{l}\text { Sangat } \\
\text { rendah }\end{array}$ & 57,14 & Rendah & 36,33 & $\begin{array}{l}\text { Sangat } \\
\text { rendah }\end{array}$ \\
\hline
\end{tabular}

Berdasarkan Tabel 5 di atas yaitu kriteria kemampuan representasi matematis dalam menyelesaikan soal representasi matematis materi barisan dan deret berdasarkan gaya belajar, diperoleh kemampuan representasi visual setiap kelompok gaya belajar memiliki kriteria yaitu rendah dan sangat rendah atau belum mampu membuat representasi visual dari sebuah masalah matematis, membuat persamaan atau model matematis dari permasalahan atau informasi yang diberikan dan menuliskan langkah-langkah penyelesaian dengan kata-kata. Pada kemampuan representasi simbolik setiap kelompok gaya belajar memiliki kriteria yaitu rendah dan sedang hanya untuk gaya belajar auditorial atau mampu membuat representasi visual dari sebuah masalah matematis, membuat persamaan atau model matematis dari permasalahan atau informasi yang diberikan dan menuliskan langkah-langkah penyelesaian dengan 
kata-kata. Pada kemampuan representasi verbal setiap kelompok gaya belajar memiliki kriteria yaitu rendah dan sangat rendah atau belum mampu membuat representasi visual dari sebuah masalah matematis, membuat persamaan atau model matematis dari permasalahan atau informasi yang diberikan dan menuliskan langkah-langkah penyelesaian dengan kata-kata. Berikut Tabel 6 kriteria keseluruhan hasil perolehan skor tes kemampuan representasi matematis setiap gaya belajar siswa.

Tabel 6. Kriteria Keseluruhan Hasil Perolehan Skor Tes Kemampuan Representasi Matematis Setiap Gaya Belajar Siswa

\begin{tabular}{cccc} 
No. & Gaya Belajar & $\begin{array}{c}\text { Rata-rata Kemampuan } \\
\text { Representasi Matematis }\end{array}$ & Kategori \\
\hline 1 & Visual & 51,59 & Sangat rendah \\
\hline 2 & Auditorial & 64,29 & Sedang \\
\hline 3 & Kinestetik & 49,89 & Sangat rendah \\
\hline
\end{tabular}

Berdasarkan hasil Tabel 6 yaitu kriteria keseluruhan hasil perolehan skor tes representasi matematis berdasarkan gaya belajar siswa diperoleh kelompok gaya belajar visual memiliki nilai rata-rata kemampuan representasi matematis sebesar 51,59 dengan kategori sangat rendah atau belum mampu membuat representasi visual dari sebuah masalah matematis, membuat persamaan atau model matematis dari permasalahan atau informasi yang diberikan dan menuliskan langkah-langkah penyelesaian dengan kata-kata. Pada kelompok siswa dengan kategori gaya belajar auditorial memiliki nilai rata-rata kemampuan representasi matematis paling tinggi sebesar 64,29 dengan kategori sedang atau mampu membuat representasi visual dari sebuah masalah matematis, membuat persamaan atau model matematis dari permasalahan atau informasi yang diberikan dan menuliskan langkah-langkah penyelesaian dengan kata-kata. Kelompok siswa dengan kategori gaya belajar kinestetik memiliki nilai rata-rata kemampuan representasi matematis sebesar 49,89 dengan kategori sangat rendah atau belum mampu membuat representasi visual dari sebuah masalah matematis, membuat persamaan atau model matematis dari permasalahan atau informasi yang diberikan dan menuliskan langkah-langkah penyelesaian dengan kata-kata.

\section{Kemampuan Representasi Matematis Siswa dengan Gaya Belajar Visual}

Berdasarkan hasil penelitian, siswa yang bergaya belajar visual sebanyak 21 siswa. Terdapat 3 siswa yang memiliki kemampuan representasi matematis dengan kategori tinggi, 2 siswa memiliki kemampuan representasi matematis dengan kategori sedang, 7 siswa memiliki kemampuan representasi matematis dengan kategori rendah dan 9 siswa memiliki kemampuan representasi matematis dengan kategori sangat rendah. Sehingga dapat dilihat bahwa kemampuan representasi matematis siswa yang memiliki gaya belajar visual dominan berada pada kategori sangat rendah. Ditunjukkan dengan nilai rata-rata yang diperoleh yaitu 51,59. 
Siswa yang memiliki gaya belajar visual rata-rata memiliki kemampuan representasi matematis secara visual sangat rendah. Hal ini ditunjukkan dengan nilai rata-rata pada representasi visual siswa yaitu 48,81. Diperkuat dengan hasil wawancara, guru menyatakan bahwa representasi visual siswa bergaya belajar visual sangat rendah dikarenakan saat pembelajaran materi barisan dan deret dilaksanakan secara daring sehingga dalam penyampaian materi oleh guru kurang optimal. Banyak dari siswa yang memiliki gaya belajar visual kurang tepat dalam menggambarkan suatu ide permasalahan ke dalam bentuk gambar dan tabel. Siswa mengatakan tidak dapat menjelaskan ide permasalahan dengan lancar dalam bentuk gambar dan tabel, siswa mengaku kurang memahami materi barisan dan deret secara menyeluruh. Banyak siswa keliru dalam memberikan keterangan pada tabel dan penempatan untuk keterangan selisih. Siswa belum mampu memahami soal dengan baik kemudian mendata nilai apa saja yang diketahui pada soal ke dalam tabel. Terdapat beberapa siswa yang menggambar sebuah tabel beserta keterangan harga dan 5 siswa tidak bisa menjawab sama sekali. Hal ini sejalan dengan hasil penelitian Febrian dkk (2016) yang mengemukakan bahwa kemampuan representasi visual siswa yang bergaya belajar visual memiliki kriteria rendah atau siswa belum mampu untuk membuat grafik, langkah-langkah pengerjaan dan perhitungan secara benar.

Sedangkan beberapa siswa sudah mampu menggambarkan suatu ide permasalahan ke dalam bentuk grafik. Banyak siswa yang menggambar grafik dengan benar dan lengkap. Berdasarkan hasil wawancara siswa dapat menjelaskan dengan lancar ide permasalahan dalam bentuk grafik dan siswa mengaku dapat memahami soal dengan baik. Beberapa siswa ada yang menggambar grafik terbalik dalam menaruh keterangan bulan dan jumlah. Kemudian ada beberapa siswa yang tidak menggambar sebuah grafik melainkan sebuah digram batang. Siswa yang memiliki gaya belajar visual cenderung teliti dan detail ketika membuat grafik dan tabel (Marifah dkk, 2020).

Nilai rata-rata pada representasi simbolik siswa dengan gaya belajar visual yaitu 57,54 dengan kategori rendah. Saat menuliskan rumus jumlah barisan geometri tak hingga siswa masih banyak keliru. Begitu pula dalam mencari harga tiket termurah, banyak siswa yang tidak bisa menuliskan rumus dan menjawab soal. Sedangkan dalam menuliskan rumus jumlah $\mathrm{n}$ suku pertama dan rumus suku ke $\mathrm{n}$ barisan arimetika, beberapa siswa sudah mampu dan dapat menemukan solusi dengan benar. Hal ini diperkuat dari hasil wawancara yaitu siswa menjelaskan bahwa kurang memahami soal dan tidak mengerti bagaimana cara mengerjakan soal. Hal itu membuat siswa membuka kembali buku miliknya dan berusaha mengingat rumus. Terlihat bahwa kurangnya pengetahuan dan pemahaman konsep berpengaruh pada representasi matematis yang siswa miliki (Bagus, 2018).

Nilai rata-rata pada representasi verbal siswa dengan gaya belajar visual yaitu 44,05 dengan kategori sangat rendah. Saat wawancara, siswa menjelaskan bahwa dalam menuliskan kesimpulan siswa hanya menuliskan dengan kata-kata solusi yang telah didapatkan. Berdasarkan paparan di atas diketahui bahwa kemampuan representasi visual siswa dalam menggambarkan suatu ide 
permasalahan ke dalam bentuk gambar dan tabel kurang tepat namun sudah mampu menggambarkan suatu ide permasalahan ke dalam bentuk grafik. Kemudian untuk kemampuan simbolik siswa berkategori rendah dan kemampuan verbal siswa berkategori sangat rendah.

\section{Kemampuan Representasi Matematis Siswa dengan Gaya Belajar Auditorial}

Berdasarkan hasil penelitian, siswa yang bergaya belajar auditorial sebanyak 14 siswa. Terdapat 2 siswa yang memiliki kemampuan representasi matematis dengan kategori tinggi, 6 siswa memiliki kemampuan representasi matematis dengan kategori sedang, 3 siswa memiliki kemampuan representasi matematis dengan kategori rendah dan 3 siswa memiliki kemampuan representasi matematis dengan kategori sangat rendah. Sehingga dapat dilihat bahwa kemampuan representasi matematis siswa yang memiliki gaya belajar auditorial dominan berada pada kategori sedang. Ditunjukkan dengan nilai rata-rata yang diperoleh yaitu 64,29. Kemampuan representasi matematis siswa bergaya belajar auditorial memiliki rata-rata paling tinggi dibandingkan dengan gaya belajar yang lain. Hal itu sejalan dengan penelitian yang telah dilakukan Febrian dkk (2016) yang menyatakan bahwa pada kelompok siswa dengan kategori gaya belajar auditori memiliki persentase yang paling tinggi dibandingkan kelompok gaya belajar visual dan kinestetik.

Siswa yang memiliki gaya belajar auditorial rata-rata memiliki kemampuan representasi matematis secara visual rendah. Hal ini ditunjukkan dengan nilai rata-rata pada representasi visual siswa yaitu 61,91. Banyak dari siswa yang memiliki gaya belajar auditorial kurang tepat dalam menggambarkan suatu ide permasalahan ke dalam bentuk tabel dan grafik. Beberapa siswa masih keliru dalam memahami soal kemudian mendata nilai apa saja yang diketahui pada soal ke dalam tabel. Kemudian dalam bentuk grafik, beberapa siswa menggambar grafik terbalik saat menaruh keterangan bulan dan jumlah. Hal ini sejalan dengan hasil penelitian yang telah dilakukan oleh Marifah dkk (2020) yaitu siswa dengan gaya belajar auditorial mengalami kendala dalam menyelesaikan permasalahan dengan representasi visual, siswa sering keliru dalam membuat unsurunsur pada grafik dan tabel.

Sedangkan banyak siswa sudah cukup benar dalam menggambarkan suatu ide permasalahan dalam bentuk gambar namun terdapat sedikit kekeliruan. DePorter dan Hernacki (2006) mengatakan bahwa salah satu ciri-ciri gaya belajar auditorial yaitu memiliki masalah dalam menyelesaikan pekerjaan yang melibatkan visualisasi seperti memotong bagian-bagian satu sama lain. Hal ini diperkuat juga dengan hasil wawancara siswa yaitu banyak siswa sudah menggambar ide permasalahan dalam sebuah gambar dengan menggambar sebuah kelereng jatuh kemudian memantul. Beberapa siswa lainnya menggambar sebuah kelereng yang memantul tetapi tidak memberikan keterangan ketinggian kelereng. 
Nilai rata-rata pada representasi simbolik siswa dengan gaya belajar auditorial yaitu 67,86 dengan kategori sedang. Banyak siswa yang sudah bisa menuliskan rumus barisan geometri tak hingga. Tetapi dalam mencari harga tiket termurah, banyak siswa yang tidak bisa menuliskan rumus dan menjawab soal. Sedangkan dalam menuliskan rumus jumlah n suku pertama dan rumus suku ke $\mathrm{n}$ barisan arimetika, beberapa siswa sudah mampu menuliskannya serta mendapatkan solusi dengan benar. Hal ini diperkuat dengan hasil wawancara yaitu siswa menjelaskan bahwa sudah dapat menuliskan rumus dan menjelaskan rumus tersebut dengan benar. Siswa mengaku membuka kembali buku miliknya dan berusaha mengingat rumus. Sejalan dengan penelitian yang dilakukan oleh Komala dan Afrida (2020) yaitu pada kemampuan representasi simbolik kelompok gaya belajar auditorial memiliki kriteria yang sama yaitu sedang atau cukup.

Nilai rata-rata pada representasi verbal siswa dengan gaya belajar visual yaitu 57,14 dengan kategori rendah. Ada beberapa siswa yang dapat menuliskan langkah-langkah mengerjakan soal dengan kata-kata yaitu menyimpulkan solusi yang telah didapatkan dengan benar namun banyak juga siswa yang keliru. Beberapa siswa yang ada yang tidak memakai kata-kata yang jelas dalam menyimpulkan dan beberapa siswa ada yang tidak bisa menuliskan kesimpulan serta tidak menjawab soal. Hal ini diperkuat dari hasil wawancara, siswa menjelaskan bahwa tidak bisa menyimpulkan jawaban yang telah didapatkan dan kurang memahami soal yang diberikan. Kecendrungan kemampuan representasi matematis dapat diketahui berdasarkan gaya belajar siswa. Sesuai dengan pernyataan Widayanti (2013) yaitu setiap siswa memiliki cara yang paling mudah untuk belajar dan untuk menyerap informasi.

\section{Kemampuan Representasi Matematis Siswa dengan Gaya Belajar Kinestetik}

Berdasarkan hasil penelitian, siswa yang bergaya belajar visual sebanyak 25 siswa. Terdapat 2 siswa yang memiliki kemampuan representasi matematis dengan kategori tinggi, 2 siswa memiliki kemampuan representasi matematis dengan kategori sedang, 7 siswa memiliki kemampuan representasi matematis dengan kategori rendah dan 14 siswa memiliki kemampuan representasi matematis dengan kategori sangat rendah. Sehingga dapat dilihat bahwa kemampuan representasi matematis siswa yang memiliki gaya belajar kinestetik dominan berada pada kategori sangat rendah. Ditunjukkan dengan nilai rata-rata yang diperoleh siswa yaitu 49,89. Hal ini didukung dengan penelitian yang dilakukan oleh Silitonga (2020) yang menyatakan bahwa tes kemampuan representasi matematis siswa bergaya belajar kinestetik merupakan rata-rata yang paling rendah dibandingkan dengan siswa bergaya belajar auditori dan visual.

Siswa yang memiliki gaya belajar kinestetik rata-rata memiliki kemampuan representasi matematis secara visual sangat rendah. Hal ini ditunjukkan dengan nilai rata-rata pada representasi visual siswa yaitu 54,33. Banyak dari siswa yang memiliki gaya belajar kinestetik kurang tepat dalam 
menggambarkan suatu ide permasalahan ke dalam bentuk grafik. Berdasarkan hasil yang diperoleh siswa bergaya belajar kinestetik menggambar grafik terbalik dalam menaruh keterangan bulan dan jumlah. Febrian dkk (2016) mengatakan bahwa siswa dengan gaya belajar kinestetik cenderung rumit menerjemahkan hasil pengerjaan kedalam bentuk grafik.

Beberapa siswa dalam menggambarkan suatu ide permasalahan dalam bentuk gambar dan tabel terdapat sedikit kekeliruan. Siswa yang memiliki gaya belajar kinestetik cenderung kurang mampu mengilustrasikan gambar dalam menyelesaikan permasalahan pada soal tes (Marifah dkk, 2020). Beberapa siswa menggambar ide permasalahan dalam sebuah gambar yaitu dengan menggambar sebuah kelereng jatuh tetapi tidak menggambar kelereng memantul. Beberapa siswa lainnya menggambar sebuah kelereng yang memantul tetapi tidak memberikan keterangan ketinggian kelereng. Beberapa siswa keliru dalam memberikan keterangan pada tabel dan penempatan untuk keterangan selisih. Beberapa siswa belum mampu memahami soal dengan baik kemudian mendata nilai apa saja yang diketahui pada soal ke dalam tabel. Hal ini diperkuat dengan hasil wawancara yaitu siswa sudah dapat menjelaskan ide permasalahan dengan baik namun sedikit keliru dalam bentuk tabel dan gambar.

Nilai rata-rata pada representasi simbolik siswa dengan gaya belajar kinestetik yaitu 59,00 dengan kategori rendah. Beberapa siswa sudah mampu menuliskan rumus dan mendapatkan solusi dengan benar. Namun beberapa siswa lainnya menuliskan rumus jumlah barisan geometri tak hingga masih keliru. Begitu pula dalam mencari harga tiket termurah, beberapa siswa tidak bisa menuliskan rumus sehingga tidak menjawab soal. Sedangkan nilai rata-rata kemampuan representasi simbolik siswa bergaya belajar kinestetik lebih tinggi dibandingkan dengan kemampuan representasi visual dan verbal. Hal ini sejalan dengan penelitian yang telah dilakukan oleh Febrian dkk (2016) yang menjelaskan bahwa kemampuan representasi simbolik lebih tinggi dibandingkan dengan kemampuan representasi lainnya, menunjukkan bahwa siswa dengan gaya belajar kinestetik cenderung untuk menyerap pembelajaran melalui pengajaran yang dilakukan guru ke arah simbolik, seperti pada saat memberikan contoh soal, latihan soal dan ulangan.

Nilai rata-rata pada representasi verbal siswa dengan gaya belajar kinestetik yaitu 36,33 dengan kategori sangat rendah. Banyak siswa yang keliru dalam menuliskan langkah-langkah mengerjakan soal dengan kata-kata yaitu menyimpulkan solusi yang telah didapatkan. Beberapa siswa yang tidak memakai kata-kata yang jelas dalam menyimpulkan dan beberapa siswa ada yang tidak bisa menuliskan kesimpulan serta tidak menjawab soal. Hal ini diperkuat dari hasil wawancara. Siswa menjelaskan bahwa dalam menuliskan kesimpulan siswa hanya menuliskan dengan kata-kata solusi yang telah didapatkan tetapi banyak dari siswa yang keliru dalam mendapatkan solusi sehingga kurang tepat dalam menuliskan kesimpulan. Sejalan dengan Komala dan Suryadi (2018) yang menyatakan bahwa keberagaman jawaban siswa yang ditemukan dari hasil kemampuan representasi 
dipengaruhi oleh kemampuan awal matematika siswa dan merupakan wujud dari strategi penyelesaian dalam menyelesaikan soal tes kemampuan representasi yakni kemampuan visual, simbolik dan verbal yang diberikan berdasarkan kebiasaan berpikir masing-masing siswa.

\section{KESIMPULAN}

Berdasarkan hasil penelitian, hasil analisis data dan wawancara serta pembahasannya maka kesimpulan yang diperoleh dari penelitian ini adalah sebagai berikut:

1. Kemampuan representasi matematis siswa bergaya belajar visual sebesar 51,59 berkategori sangat rendah. Kemampuan representasi matematis siswa bergaya belajar auditorial sebesar 64,29 berkategori sedang. Kemampuan representasi matematis siswa bergaya belajar kinestetik sebesar 49,89 berkategori sangat rendah.

2. Kemampuan representasi matematis siswa bergaya belajar auditorial memiliki kategori paling tinggi dibandingkan dengan siswa bergaya belajar visual dan kinestetik.

\section{UCAPAN TERIMA KASIH}

Penyusunan penelitian ini tidak terlepas dari doa, arahan, bimbingan, bantuan, dan peran serta berbagai pihak. Oleh karena itu, pada kesempatan ini penulis menyampaikan terima kasih kepada:

1. Bapak Dr. H. Sudi Prayitno, M.Si. selaku dosen pembimbing I dan Ibu Nourma Pramestie Wulandari, S.Pd., M.Pd. selaku dosen pembimbing II

2. Bapak M. Laduni, M.Pd. selaku guru matematika SMA Negeri 4 Praya yang telah membantu dalam pelaksanaan penelitian.

3. Bapak Kadian, S.Pd., M.Pd. selaku kepala sekolah SMA Negeri 4 Praya yang telah memberikan izin melakukan penelitian, serta seluruh guru, karyawan, siswa kelas XII MIPA 4 dan XII MIPA 6 SMAN 4 Praya yang telah membantu dan memberikan dukungan selama penelitian.

4. Keluarga dan teman-temanku yang telah bersedia memberikan motivasi dan membantu dalam menyelesaikan penelitian (Lalu Wirentangun,A.Ptnh. M.H. dan Tri Yuliana).

\section{DAFTAR PUSTAKA}

Anggraeni, W., \& Suyahya, I. (2016). Prediksi Prestasi Belajar Kewirausahaan Siswa SMKN 3 Depok Berdasarkan Gaya Belajar Menggunakan Aturan Mamdani. Research and Development Journal of Education Vol.3 No.1 Hal 70-88. https://doi.org/10.30998/rdje.v3i1.1451

Bagus, C. (2018). Analisis Kemampuan Representasi Matematis Siswa dalam Menyelesaikan Soal Lingkaran pada Kelas VII-B MTS Assyafi'iyah Gondang. Suska Journal of Mathematics Education Vol.4 No.2 Hal 115-124. https://doi.org/10.24014/sjme.v4i2.5234

Dahlan, J. A., \& Juandi, D. (2011). Analisis Representasi Matematik Siswa Sekolah Dasar dalam Penyelesaian Masalah Matematika Kontekstual. Jurnal Pengajaran Matematika dan Ilmu Pengetahuan Alam Vol.16 No.1 Hal 128-138. https://doi.org/10.18269/jpmipa.v16i1.273 
DePorter, B., \& Hernacki, M. (2006). Quantum Learning (Membiasakan Belajar Nyaman dan Menyenangkan. Bandung: Kaifa Learning.

Febrian, G., Sinaga, M., \& Hartoyo, A. (2016). Kemampuan Representasi Matematis Siswa Ditinjau dari Gaya Belajar pada Materi Fungsi Kuadrat di SMA. Jurnal Pendidikan dan Pembelajaran Khatulistiwa Vol.16 No.1 Hal 1-12.

Kemendikbud. (2016). Permendikbud Nomor 22 Tahun 2016 Tentang Standar Proses Pendidikan dan Menengah. Jakarta: Kemendikbud.

Komala, E., \& Afrida, A. M. (2020). Analisis Kemampuan Representasi Matematis Siswa SMK Ditinjau dari Gaya Belajar. Journal of Instructional Mathematics Vol.1 No.2 Hal 53-59. https://doi.org/10.37640/jim.v1i2.364

Komala, E., \& Suryadi, D. (2018). Analysis of internal and external mathematical representation ability to senior high school students in Indonesia. Journal of Physics: Conference Series Vol.1132 No.1 Hal 0-10. https://doi.org/10.1088/1742-6596/1132/1/012047

Lestari, K. E., \& Yudhanegara, M. R. (2017). Analisis Kemampuan Representasi Matematis Mahasiswa pada Mata Kuliah Geometri Transformasi Berdasarkan Latar Belakang Pendidikan Menengah. Jurnal Matematika Integratif Vol.13 No.1 Hal 28-33. https://doi.org/10.24198/jmi.v13i1.11410

Marifah, W. N., Rufiana, I. S., \& Wahyudi, W. (2020). Analisis Kemampuan Representasi Visual Siswa Pada Materi Pengolahan Data Ditinjau Dari Gaya Belajar Vak. J-PiMat: Jurnal Pendidikan Matematika Vol.2 No.2 Hal 175-186. https://doi.org/10.31932/j-pimat.v2i2.875

Mite, Y., Corebima, A., \& Syamsuri, I. (2016). Hubungan Antara Gaya Belajar dengan Hasil Belajar Siswa SMA Katolik Santa Maria Malang Berbasis Skor Terkoreksi dalam Pembelajaran Biologi melalui Pembelajaran Group Investigation (GI) Tahun Ajaran 2015/2016. Jurnal Pendidikan Teori, Penelitian, dan Pengembangan Vol.1 No.5 Hal 822-827. https://doi.org/10.17977/jp.v1i5.6262

NCTM. (2000). Principles and Standars for School Mathemathic. Reston VA: National Teachers of Council of Mathemathics Inc.

Nurhayati, E., \& Subekti, F. E. (2017). Deskripsi Kemampuan Penalaran Matematis Siswa Ditinjau dari Gaya Belajar dan Gender. AlphaMath: Journal of Mathematics Education Vol.3 No.1 Hal $66-78$.

Prayitno, S., Lu'luilmaknunn, U., Sridana, N., \& Subarinah, S. (2021). Analyzing the Ability of Mathematics Students as Prospective Mathematics Teachers on Multiple Mathematical Representation. Proceedings of the 2nd Annual Conference on Education and Social Science Vol.556 No.20 Hal 309-313. https://doi.org/10.2991/assehr.k.210525.096

Ridwan, M. (2017). Profil Kemampuan Penalaran Matematis Siswa Ditinjau dari Gaya Belajar. KALAMATIKA Jurnal Pendidikan Matematika Vol.2 No.2 Hal 193-206. https://doi.org/10.22236/kalamatika.vol2no2.2017pp193-206

Silitonga, R. H. Y. (2020). Perbandingan Kemampuan Representasi Matematik Berdasarkan Gaya Belajar Siswa SMP. Supermat (Jurnal Pendidikan Matematika) Vol.4 No.1 Hal 16-21. https://doi.org/10.33627/sm.v4i1.337

Tyas, W. H., \& Sujadi, I. (2016). Representasi Matematis Siswa dalam Menyelesaikan Masalah Matematika pada Materi Aritmatika Sosial dan Perbandingan Ditinjau dari Gaya Kognitif Siswa 
Kelas VII SMP Negeri 15 Surakarta Tahun Ajaran 2014 / 2015. Jurnal Elektronik Pembelajaran Matematika Vol.4 No.8 Hal 781-792.

Widayanti, F. D. (2013). Pentingnya Mengetahui Gaya Belajar Siswa dalam Kegiatan Pembelajaran di Kelas. Erudio Journal of Educational Innovation Vol.2 No.1 Hal 7-21. https://doi.org/10.18551/erudio.2-1.2

Yenni, \& Sukmawati, R. (2020). Analisis Kemampuan Representasi Matematis Mahasiswa Berdasarkan Motivasi Belajar. Mosharafa: Jurnal Pendidikan Matematika Vol.9 No.2 Hal 251262.

How to cite : Ramadhana, B. R., Prayitno, S., Wulandari, N. P., Subarinah, S., 2022. Analisis Kemampuan Representasi Matematis pada Materi Barisan dan Deret Berdasarkan Gaya Belajar. Jurnal Riset Pendidikan Matematika Jakarta. 4(1). 46-59. https://doi.org/10.21009/jrpmj.v4i1.23025

To link to this article: https://doi.org/10.21009/jrpmj.v4i1.23025 